\title{
Education and Training: Issues for the Field of Interior Design
}

James H. Banning (Corresponding Author)

School of Education, Colorado State University,

1588 Education, Fort Collins, Colorado 80523

Tel: 970-491-7153 E-mail: James.Banning@ColoState.edu

Stephanie Clemons

Dept. of Design \& Merchandising

1574 Aylesworth, Fort Collins, Colorado 80523

Tel: 970-491-5639 E-mail: Stephanie.Clemons@ColoState.edu

Chad W. Gibbs

School of Family Life, Brigham Young University,

2056 JFSB, Provo, Utah 82602

Tel: 801-602-9946 E-mail: chadgibbs@byu.edu

David A. McKelfresh

Division of Student Affairs, Colorado State University

201 Administration, Fort Collins, Colorado 80523

Tel: 970-419-4722 E-mail: David.Mckelfresh@ColoState.edu

Received: November 29, 2013 Accepted: December 20, 2013 Published: December 31, 2013

doi:10.5296/jet.v1i1.4796 URL: http://dx.doi.org/10.5296/jet.v1i1.4796 


\section{Abstract}

Interior design as a discipline shares much with architecture, art history, and environmental psychology, but the core and issues of a discipline can be found in its graduate education research. It is in graduate research that important topics are rigorously explored by faculty and students. The purpose of this study was to examine the educational and training topics being explored at the doctoral level in interior design. The study utilizes a bounded qualitative meta-study framework to examine 38 dissertation abstracts from 1999 through 2009 found by searching the terms interior design and education or teaching in the ProQuest Dissertation and Theses ${ }^{\mathrm{TM}}$ digital database. The overarching research question for this study was: What can we learn from examining doctoral dissertations abstracts found during this 10 year time period that focus on the teaching of interior design? The study provides an overview of qualitative meta-syntheses within a bounded qualitative framework. The content of the study's findings addresses the attributes of the researcher and the research of interior design education. We conclude by calling for a discussion of doctoral research and interior design instruction focusing on the relationship of professional practice and academic research and the utilization of qualitative meta-analysis as a tool for establishing evidence based design.

Keywords: interior design research, qualitative meta-study

\section{Introduction}

The number of individuals acquiring doctorate degrees is increasing. The number of doctorates awarded in the United States increased from 44,446 in 1994-1995 to 67,716 in 2008-2009 (National Center for Educational Statistics, 2011). Interior design related doctorate degrees are a relatively new phenomenon. Today, of the 61 United States institutions listing their graduate programs with the Interior Design Educators Council (IDEC), 14 offer a Ph.D. (Interior Design Educators Council, 2011). For the interior design discipline, the master's is considered the terminal degree (Interior Design Educators Council, 2006). However, employment announcements, particularly at research institutions, continue to request a doctorate degree for those individuals who desire to teach fulltime and achieve tenure and promotion in the higher education arena. This demand has come at the same time that there is a dearth of educators to handle the teaching demand in the field of interior design education (Kimball Office Work Group, 2009).

It is important to develop theory and research from within the discipline of interior design (White \& Dickson, 1994). A distinct and separate body of knowledge based on theory related to interior design has been in demand for years (Dickson \& White, 1993). Doctoral dissertations serve as one avenue for increasing the knowledge in the field of interior design.

The overarching research question for this study is "What can we learn from the examination of doctoral dissertations that focus on interior design instruction from 1999 through 2009?" We addressed the question by exploring these sub-questions: What are the attributes of the researcher and research? What are the guiding frameworks for the research? What dissertations have been published in academic journals? What are the topics associated with 
the analyzed dissertations? And, finally, what are the implications of the findings for the interior design teaching profession? A bounded qualitative meta-synthesis using document analysis guided the efforts to respond to these key questions. We present our account of these matters as follows: First, we provide a brief review of the literature. Second, we discuss our meta-study framework, methods and procedures. Third, we present our findings and discussion of these findings. Finally we close with implications for interior design educators.

\section{Review of Literature}

The long history of interior design has been well documented (Pile, 2013). Of note in this history is increase in the practice of interior design after World War II and subsequently the courses at the undergraduate level began to appear at colleges and universities. It was, however, not until the 1960s and 1970s, when rapid expansion was taking place in higher education, that the first graduate degrees related to interior design were conferred. In the mid-1960s, Florida State University offered one of the first doctoral programs with a focus on interior design. FSU was followed closely by the University of Missouri, which graduated its first interior design doctoral candidate in 1972. Around the same time, the University of Tennessee established a multidisciplinary doctoral program that was later dissolved (White \& Dickson, 1994). As summarized by White \& Dickson (1994, p.28) "The university climate forced interior design subject matter to evolve from that of a craft to an academic subject"

A doctoral education plays a critical role in producing an educated and engaged citizenry that is essential to America's prosperity (Council of Graduate Schools, 2011). While the first professional degree in interior design is to establish broad-based knowledge in the profession (White \& Dickson, 1994), the advanced degree offers an opportunity to build on an existing foundation in the interior design field, focus on generating and/or reinterpreting knowledge, and develop or test theories that are critical to the growth of the field (Dickson \& White, 1993). Interior design doctoral students can address a myriad of broader social issues through the application of design principles. For example, they can help solve problems related to the health care needs of the baby boomers, the impact of the economy on office design, and the complexity of designing the residential interior. They can also create a foundation of theory for interior design education. This need for a foundation calls for members of the profession to acquire post-professional graduate degrees because research "constitutes the backbone of any profession and is what separates [a profession] from a trade school discipline" (Dickson \& White, 1993, p. 4).

\section{A Bounded Qualitative Meta-Synthesis Methodology}

Noblit and Hare (1988) pioneered the synthesis of qualitative studies. They developed and promoted a "themes of the themes" strategy under the concept of meta-ethnography. Major and Savin-Baden (2010) sought "a better approach for making sense of existing research" (p.10) as did Saini and Shlonsky (2012). Both sets of authors saw the qualitative meta-synthesis approach as an important tool in establishing evidence based research to support informed practice, and as a tool that can be used in concert with traditional quantitative meta-analysis. 
This study used a bounded qualitative synthesis framework (Banning \& Folkestad, 2012; Banning \& Kuk, 2009, 2011). Unlike a typical quantitative meta-analysis, this study is "bounded" by both a search of a specific research genre (the doctoral dissertation abstract) and a specific time period. To guide the analysis, the study used qualitative document analysis (Altheide, Coyle, DeVriese, \& Schneider, 2008) as the framework as well as a meta-study approach (Paterson, Thorne, Canam \& Jillings, 2001). The latter focused the analysis not only on the study findings, but on the particular methods and theories employed in the studies.

\subsection{Sample \& Procedures}

Using the ProQuest Dissertation and Theses ${ }^{\mathrm{TM}}$ digital database for dissertations from 1999 through 2009, a 10 year time frame was selected to provide for a reasonable number of dissertations for examination and the year 2009 was selected for the stop year to allow for enough time for dissertations to be published by the time the study was implemented. Dissertation citations and abstracts were searched using the search terms interior design and education or teaching. This search procedure produced 154 abstracts for possible inclusion in the study. Master level theses, foreign language dissertations, and dissertations that did not relate to aspects of teaching and instruction in the field of interior design were excluded. This procedure left for inclusion doctoral dissertations in English between 1999 and 2009 focusing on teaching and instruction in interior design. Three of the study's authors reviewed the abstracts and reached consensus to include 38 in this study.

The selected abstracts were downloaded from the ProQuest Dissertation and Theses TM database base to the bibliographic software EndNotes. ${ }^{\mathrm{TM}}$ They were then exported to a word processor and prepared for importation into NVivo 9.0. ${ }^{\mathrm{TM}}$ NVivo was used to code the abstracts for both researcher and research attributes and to assist in developing a topical structure.

\subsection{Method of Analysis}

Qualitative document analysis (QDA) (Altheide et al., 2008; Schwandt, 2007) provided the methodological framework. The researchers used the template analysis method (King, 1998) to code the abstracts using both deductive and inductive coding. Researcher attributes and the research itself were established as deductive codes; inductive codes were developed for topical coding of the dissertation abstracts. The researchers applied constant comparative analysis (Corbin \& Strauss, 2008) to the inductive codes, which enabled the construction of a thematic topical structure for the dissertation abstracts.

\subsection{Trustworthiness}

The researchers used peer examination (Creswell, 2007) to establish which abstracts would be included and to develop the inductive coding process for the topical analysis. The peer examination process involved discussing issues and reaching consensus. The peer examination process represented research collaboration (Paulus, Woodside, \& Ziegler, 2008) among the authors, which included a qualitative research professor, two interior design professionals, and a campus assessment professional. 


\section{Findings: Deductive Analysis}

The next sections present the findings of the deductive coding. The a prior categories within the template analysis approach (King, 1998) for this study included the researcher attributes of gender, degree type, and national location. The a prior categories regarding the research activity included type of methodology, year of research, institutions awarding the degree, the guiding theory framework for the research, and the publication record of the research.

\subsection{Researcher and Research Attribute Results}

The researcher and doctoral research attributes related to interior design instruction are presented in Table 1. Researchers were overwhelmingly female (84\% versus $16 \%)$ and considerably more researchers were completing the Ph.D. than the Ed.D. (95\% versus 5\%).

Of the dissertations analyzed, $42 \%$ were quantitative and $38 \%$ were qualitative. Sixteen percent of the dissertations were conceptual-historical dissertations and one reported research study used a mixed methods approach.

Table 1. Distribution of Researcher and Research Attributes

\begin{tabular}{|c|l|l|}
\hline Attributes & Numbers & Percentages \\
\hline Researcher Attributes & & \\
\hline Gender/Female & 32 & 84 \\
\hline Gender/Male & 6 & 16 \\
\hline Ph.D. & 36 & 95 \\
\hline Ed.D. & 2 & 5 \\
\hline International Institutions & 6 & 16 \\
\hline U.S. Institutions & 32 & 84 \\
\hline Research Attributes & & \\
\hline Method/Quantitative & 16 & 42 \\
\hline Method/Qualitative & 15 & 39 \\
\hline Method/Mixed & 1 & 3 \\
\hline Conceptual/Historical & 6 & 16 \\
\hline
\end{tabular}

Thirty-eight dissertations were completed between the years 1999 through 2009; more than two-thirds (27) of those were completed prior to 2005 (Table 2). The remaining dissertations were completed from 2005 through 2009, although there were no dissertations in the years 2007 and 2008 that met the search parameters. The year 2001 was the most productive year with eight dissertations. 
Table 2. Distribution of Dissertations by Year

\begin{tabular}{|c|c|}
\hline Year & Number of Dissertations \\
\hline 1999 & 5 \\
\hline 2000 & 3 \\
\hline 2001 & 8 \\
\hline 2002 & 3 \\
\hline 2003 & 4 \\
\hline 2004 & 4 \\
\hline 2005 & 5 \\
\hline 2006 & 3 \\
\hline 2007 & 0 \\
\hline 2008 & 0 \\
\hline 2009 & 3 \\
\hline TOTAL & 38 \\
\hline
\end{tabular}

Twenty-nine different degree granting institutions awarded degrees. Table 3 lists the six institutions that awarded two or more doctoral degrees during the study's time period. With four degrees granted, the University of Minnesota awarded the most doctoral degrees. As noted in Table 1, six or $16 \%$ of the dissertations were completed by students at institutions outside the United States.

Table 3. Alphabetical Listing of Institutions Awarding Degrees

\begin{tabular}{|l|l|}
\hline Institution & Total \\
\hline University of Minnesota & 4 \\
\hline Iowa State University & 3 \\
\hline Ohio State University & 3 \\
\hline Capella University & 2 \\
\hline Oklahoma State University & 2 \\
\hline Purdue University & 2 \\
\hline TOTAL & 16 \\
\hline
\end{tabular}




\subsection{Guiding Frameworks Results}

To address the theory component of the meta-study model (Paterson et al., 2001), each dissertation abstract was examined using a classification system developed by Banning and Folkestad (2012) to see what guiding framework was mentioned, if any. The theoretical guiding framework was defined within this study as any use of paradigmatic statements, grand theories, theories of middle range, substantive theories, or models to guide the research. Research guided by a survey or inventory research instrument (Banning \& Kuk, 2011) was assigned to the instrument guiding framework category. If previous research was cited in the abstract, then the literature guiding framework was employed. The results of this classification system as applied to the 38 abstracts are included in Table 4 . Only $32 \%$ of the abstracts mentioned a guiding framework and only six abstracts mentioned a named theory or model.

Table 4. Guiding Frameworks

\begin{tabular}{|l|l|l|}
\hline Type of Framework & Number & Percentage \\
\hline No Frameworks mentioned & 26 & 68 \\
\hline Named theory or model & 6 & 16 \\
\hline Literature & 4 & 11 \\
\hline Instrument & 2 & 5 \\
\hline
\end{tabular}

\subsection{Publishing of the Dissertations}

Two sources were reviewed to answer the question of how many of the study's interior design education related dissertations were eventually published in academic journals: the Journal of Interior Design and the Academic Search ${ }^{T M}$ Premier database. The latter covers more than 8,500 abstracted and indexed journals including the following titles related to the study: Interiors, Interior Design (Whitney), Interior Design (Reed), and Art, Design, and Communications in Higher Education. Of the 38 dissertations in the study, only one was found to be published. In 2003, Bender's (2002) dissertation entitled "Interior Design Faculty Intentions to Adopt Distance Education" was published in The Journal of Interior Design.

\section{Findings: Inductive Topical Results}

The template analysis method allows for the development of inductive codes or categories driven by the content of the data (King, 1998). Using the method of constant comparative analysis (Corbin \& Strauss, 2008) each dissertation topic was given a descriptive code and then compared and contrasted with all other assigned codes. From this list of codes a thematic categorical structure was induced that organized the dissertation topics into four major categories: informing content for teaching, alternative delivery, teaching strategies, and teaching environment and facilities. See Appendix 1. for a listing of dissertations classified by the foregoing categories. While some dissertations related to several topic areas, each 
dissertation was assigned only to the most representative topic.

\subsection{Informing Content for Teaching}

This category focused on course content possibilities and not on the processes associated with teaching interior design. Nineteen of the dissertations were placed in this category. This category included topics such as the influence of historical periods and events both in the U.S. and Europe on the arts, museum design, and the contributions of various aspects of the interior; for example, furniture makers, crafts people, quilters, and sustainability. In addition, other dissertations topics included looking at housing preferences, home-based work spaces, and working conditions of interior design faculty. While the dissertations in this category may not relate directly to the processes of teaching, the subject matter of the work could contribute to the course content of the interior design curriculum.

\subsection{Alternative Delivery}

Dissertations in this category focused on distance delivery; seven addressed some aspect of online teaching and computer assisted teaching. Topics included the presentation of conceptual models, assessment of interests and attitudes of students and faculty toward alternative delivery, comparative study of traditional versus alternative delivery strategies, and the evaluation of the use of the virtual environment. The role of alternative delivery strategies is presented as being used increasingly by interior design educators; the use of alternative strategies is viewed as effective and an expansion of these tools is to be expected in the future.

\subsection{Teaching Strategies}

Seven dissertations focused on the processes associated with teaching. Specific topics include strategies for improving art foundation, drawing, and spatial cognition. The role of research in teaching is discussed as well as the specific use of concept maps and embedded questions as teaching strategies.

\subsection{Teaching and the Physical Environment}

This category included those dissertations that addressed some aspect of the physical environment associated with teaching; five dissertations were included in this category. The specific topics included dissertations on teaching spaces for adult learners, the construction of classroom furniture, and the experiences associated with changing the physical environment of classrooms. In addition, one study focused on the use of the coffee shop as an alternative physical space for teaching.

\section{Discussion}

The paucity of doctoral work in interior design education is an important topic for discussion. Approximately four dissertations per year over a ten year period made up the sample of this study. The limited number of dissertations may reflect the reality that a master's degree is considered the terminal degree for the profession (Interior Design Educators Council, 2006). Although important graduate research work in interior design occurs at the master's level, the 
question can be raised whether this small amount of doctoral work can support both the need for scholarship in the field as well as scholars. It is important to note that while the master's degree may be defined as a terminal degree by the profession (Interior Design Educators Council, 2006), the Ph.D. is often the degree required for entrance into a university teaching position as well as promotion in colleges and universities.

There did not appear to be a unified or synergetic direction to the work represented in the dissertations related to interior design and teaching. While the studies were placed in four rather broad categories, there was little relationship among the studies except for broad topical content. To some degree, the alternative delivery category appeared more cohesive and less idiosyncratic than the other categories. But the notion of research being built upon previous research was difficult to discern with more than half of the abstracts making no reference to previous research. In part, this may be due to the fact that the 38 dissertations came from 29 different institutions with only six institutions producing two or more dissertations during the period of the study. This coupled with the wide variety of degree granting departments would make it difficult to find common agendas to guide the research work. This lack of focus reveals an opportunity for interior design educators at the Ph.D. level to determine research goals for the field.

In addition, only one of the dissertations was published suggesting that the research topics, while important to the researcher, may have been less important to the academic journals associated with interior design education. The finding that so few of the dissertations became a part of academic journal genre is not unique to interior design research. J. H. Banning (personal communication, October 12, 2011) reports similar findings in the fields of occupational therapy research, community college research, and student service organizational research. However, it is important to note that the primary peer reviewed journal for interior design research, the Journal of Interior Design, is published by the Interior Design Educators Council. It seems remarkable that more articles were not developed from these dissertations. In the future, ways should be explored to encourage more scholarly publications on teaching interior design.

While it is difficult to judge the quality of the research from examination of abstracts (nor was that the goal of this study), two important items for discussion emerged. One is the quality of the abstracts examined in this study. Weaknesses in the structure of the abstracts were similar to the ones Banning and Folkestad (2012) found in STEM doctoral research abstracts and also similar to the weakness addressed by Kelly and Yin's (2007) work. Kelly and Yin found that many research abstracts were lacking in background and content; had unclear purpose, objective, and research questions; provided little description of setting and population/participants; included few details regarding intervention/program; had sparse information regarding methods, research design, data collection, analysis, and findings results; and provided limited conclusions and recommendations.

In addition to the weaknesses in the construction of the abstract, the lack of mention of a guiding framework in the abstract may also suggest a lack of importance for the role of theory or previous research. Sixty-eight percent of the abstracts reviewed for this study did 
not mention a guiding framework. Only six dissertations mentioned a theory or model by name and five mentioned background literature.

The difficulty of the use of theory in interior design is not a new topic. Raein (2004) reports design students' alienation toward the teaching and learning of theory, yet interior design accreditation requires theory to be a part of the curriculum of accredited interior design programs. Theory will continue to be difficult to apply to practice as long as research in the profession is not related to theory. The important step between theory and practice is research. According to the 2011 Council for Interior Design Professional Standards, interior design professionals must be able to analyze problems from many different perspectives and synthesize information (p. 1). This standard for accreditation illustrates the importance of research findings and the role of meta-syntheses.

\section{Implications}

There are several implications that we can draw from our results. First, if research is going to support the teaching of interior design, the professional organizations associated with the interior design teaching profession should become more involved with doctoral research. By coupling interior design studio practice to academic research, many more interior design dissertation research projects with a high level of relevancy to the profession of interior design could become available. It is beyond the purview of this study and its authors to outline the specific path of involvement that the interior design teaching professions should take to be more a part of doctoral research. But, a national discussion of these findings could be a first step. This discussion could lead to both new ways of involvement in the process of doctoral research as well as in suggesting important national and professional research topics. The dissertations on alternative delivery strategies would be an example of a topic of national professional interest. To build a more symbiotic relationship between graduate research and the profession of interior design, perhaps a clearinghouse of topics could be posted on the interior design websites for students to access.

A second implication from this study relates to studio practice as an academic research movement (Sullivan, 2005). Within the field of research and arts, there is a movement to bring the act of practice and studio work into the center of research endeavors. This movement is represented by several new works: Sullivan's (2005) Art Practice as Research: Inquiry in the visual arts; Elkins' (2009) edited book, Artists with PhDs: On the New Doctoral Degree in Studio Art; and the edited book by Smith and Dean (2009), Practice-led Research, Research-led Practice in the Creative Arts. These works represent the international discussion of innovative efforts to have higher education institutions embrace the notion of studio and practice as a form of research; research worthy of the title Ph.D. dissertation. Within the three works noted above, not one chapter or index references interior design. It is understood that the field of art is not the same as the field of interior design, but both share the importance of studio work (design) and practice and the need to build more accepted research strategies related to the doctorate within the academy.

Third, the use of a qualitative-meta study approach has implications for future research and application of findings in interior design. An important movement within the field of interior 
design is the emphasis on evidence-based design (Gurerin \& Thompson, 2004; Waxman \& Clemons, 2007). Evidenced based design is a term borrowed from the medical research community (Kopec, Sinclair, \& Matthes, 2012) that recognizes the importance of including previous research in design efforts. Meta-synthesis is an important tool within the research community for establishing evidence (Cooper \& Hedges, 1994). While most meta-synthesis strategies continue to focus on quantitative methods to establish evidence, the current study illustrates the use of qualitative methods to synthesize research findings. For example, the methodology used in this study could also assist in synthesizing a number of interior design research interests, from the use of light to the personalization of space. Qualitative meta-synthesis strategies can become a valuable tool for interior design practitioners and researchers.

The first implication noted above calls for a national discussion. The additional two implications presented suggest agenda items for that discussion: practice as research and qualitative meta-study research for helping to establish evidence-based design for the field of interior design.

\section{Summary}

This study is an initial step in exploring doctoral research in interior design using the methodology of a qualitative meta-study. It is hoped that national organizations associated with the field of interior design will assist in shaping the need for a specific body of knowledge related interior design education for both current and future design educators. The issue of generating new knowledge to support the profession is critical to the foundation of the field and the growth of the profession.

\section{References}

Altheide, D. L., Coyle, M., DeVriese, K., \& Schneider, C. (2008). Emergent qualitative document analysis. In S. N. Hesse-Biber \& P. Leavy (Eds.), Handbook of emergent themes (pp. 127-154). New York: Guilford Press.

Banning, J. H., \& Folkestad, J. (2012). STEM education related dissertation abstracts: A bounded qualitative meta-study. Journal of Science Education and Technology. Advance online publication. http://dx.doi.org/10.1007/s10956-011-9361-9

Banning, J. H., \& Kuk, L. (2009). The student affairs organizational dissertation: A bounded qualitative meta-study. College Student Journal, 43(2A), 285-293.

Banning, J. H., \& Kuk, L. (2011). College housing dissertations: A bounded qualitative meta-study. The Journal of College and University Housing, 37(2), 91-105.

Bender, D. M. (2003). Interior design faculty intentions to adopt distance education. Journal ofInterior Design, 29, 66-81.

Cooper, H., \& Hedges, L. V. (1994). The handbook of research synthesis. New York, NY: Russell Sage Foundation.

Council for Interior Design Accreditation Professional Standards. Professional standards 
2011.

Retrieved

from

http://accredit-id.org/wp-content/uploads/Policy/ProfessionalStandards2011.pdf

Council of Graduate Schools in the United States. (2011). Advocacy, research, and innovation. Retrieved from http://www.cgs.org/Default.aspx?tabid=372

Corbin, J., \& Strauss, A. (2008). Basics of qualitative research (3rd ed.). Los Angeles, CA:Sage Publications.

Creswell, J. W. (2007). Qualitative inquiry \& research design (2nd ed.). Thousand Oaks, CA: Sage Publications.

Dickson, A. W., \& White, A. C. (1993). Are we speaking the same language? Practitioners' perceptions of research and the state of the profession. Journal of Interior Design, 19(1), 3-10.

Elkins, J. (Ed.). (2009). Artists with PhDs: On the new doctoral degree in studio art.Washington, DC: New Academia Publishers.

Guerin, D., \& Thompson, J. (2004). Interior design in the $21^{\text {st }}$ century: An educational transformation. Journal of Interior Design, 30(2), 1-12.

Interior Design Educators Council. (2006). IDEC position paper-graduate education. Retrieved from http://www.idec.org/pdf/ IDECWhitePaperGrad.pdf

Interior Design Educators Council. (2011). Interior design and related graduate progams. Retrieved from http://www.idec.org/students/documents/GraduatePrograms2010edited1_25_11.pdf

Kelly, A. E., \& Yin, R. K. (2007). Strengthening structured abstracts for educational research:The need for claim-based structured abstracts. Educational Record, 36(3), 133-138.

Kimball Office Work Group. (2009). Sustaining interior design education initiative. Retrieved from http://www.idec.org/careercenter/documents/SIDEPowerPoint.ppt.

King, N. (1998). Template analysis. In C. Cassell \& G. Symon (Eds.), Qualitative methods andanalysis in organizational research (pp. 118-134). London, UK. Sage Publications.

Kopec, D., Sinclair, E., \& Matthes, B. (2012). Evidence based design. Boston, MA: Prentice Hall.

Major, C. H., \& Savin-Baden, M. (2010). An introduction to qualitative research synthesis: Managing the information explosion in social science research. London, UK: Routledge.

Noblit, G.W., \& Hare, R. D. (1988). Meta-ethnography: Synthesizing qualitative studies. Newbury Park, Sage Publications.

National Center for Educational Statistics. (2011). Student effort and educational progress/completions Table A-26-1. $\quad$ Retrieved from http://nces.ed.gov/programs/coe/tables/table-dcd-1.asp 
Paterson, B. L., Thorne, S. E., Canam, C., \& Jillings, C. (2001). Meta-study of qualitative health research: A practical guide to meta-analysis and meta-synthesis. Thousand Oaks, CA: Sage.

Pile, J. F. (2013). A history of interior design. London: Laurence King Publishers.

Paulus, T., Woodside, M., \& Ziegler, M. (2008). Extending the conversation: Qualitative research as dialogic collaborative process. The Qualitative Report, 13(2), 226-243.

Raein, M. (2004). Integration of studio and theory in the teaching of graphic design. Art \& Design Communication in Higher Education, 3(3), 163-174.

Saini, M., \& Shlonsky, A. (2012). Systematic syntheses of qualitative research. New York, NY: Oxford University Press.

Schwandt, T. A. (2007). Qualitative inquiry: A dictionary of terms $\left(3^{\text {rd }}\right.$ ed.). Thousand Oaks, CA: Sage Publications.

Smith, H., \& Dean, R. T. (Eds.). (2009). Practice-led research, research-led practice in the creative arts. Edinburgh, UK: Edinburgh University Press.

Sullivan, G. (2005). Art practice as research: Inquiry in the visual arts. Thousand Oaks, CA: Sage Publications.

Waxman, L.K., \& Clemons, S. (2007). Student perceptions: Debunking television's portrayal of interior design. Journal of Interior Design, 32(2), v-xi.

White, A. C., \& Dickson, A. W. (1994). Practitioners' perceptions of interior design: Graduate education and implications for the future. Journal of Interior Design, 20(1), 27-35.

\section{Appendix}

Appendix 1. Topical/Thematic Results

\section{Informing Content for Teaching}

Catsis, C. T. (2001). Perception of opportunity for innovation and productivity in relation to subjective well-being of interior design educators at major universities in the United States.Unpublished Ph.D., Oklahoma State University, United States -- Oklahoma.

Davis, G. B. (1999). Demand at first sight: The Centennial of 1876 as a catalyst for the consumer revolution in American interior design, 1876-1893.Unpublished Ph.D., Temple University, United States -- Pennsylvania.

Dutta, A. (2001). Designing the present: The Cole Circle, and the architecture of (an) imperial bureaucracy, 1851--1901. Unpublished Ph.D., Princeton University, United States -New Jersey.

Engels-Schwarzpaul, A.-C. (2001). Myth, symbol, ornament: The loss of meaning in transition. Unpublished Ph.D., The University of Auckland (New Zealand), New Zealand.

Farr, B. R. (2000). Museum stores: Curators and marketers of culture.Unpublished Ph.D., 
Iowa State University, United States -- Iowa.

Fletcher, K. T. (1999). Environmental improvement by design: An investigation of the United Kingdom textile industry. Unpublished Ph.D., Open University (United Kingdom), England.

Goldberg, D. A. (2000). Isamu Noguchi: The artist as engineer and visionary designer, 1918--1939.Unpublished Ph.D., New York University, United States -- New York.

Jennings, T. (2005). Investigating creativity: Understanding the perspectives of teachers and students. Unpublished 3205101, Northern Illinois University, United States -- Illinois.

Kang, M. (2004). The analysis of environmentally sustainable interior design practice.Unpublished 3154052, University of Minnesota, United States -- Minnesota.

Kucko, J. K. (2003). Trinity Valley Quilters' Guild: Quiltmaking practices and motivations.Unpublished Ph.D., Texas Woman's University, United States -- Texas.

Lee, H.-J. (2005). Influence of lifestyle on housing preferences of multifamily housing residents.Unpublished 3197977, Virginia Polytechnic Institute and State University, United States -- Virginia.

MacEachren, E. J. (2001). Craftmaking: A pedagogy for environmental awareness.Unpublished Ph.D., York University (Canada), Canada.

Mazi, F. A. (2002). Family and business factors related to the exclusivity of home-based business workspace: An exploratory study.Unpublished Ph.D., University of Minnesota, United States -- Minnesota.

Moon, S.-O. (1999). Critical discourse of postmodern aesthetics in contemporary furniture: An examination on art and everyday life in art education. Unpublished Ph.D., The Ohio State University, United States -- Ohio.

Poletti-Anderson, A. J. (2002). The search for a Hungarian national style: The Fiatalok and the National Folk Movement.Unpublished Ph.D., University of Virginia, United States -Virginia.

Quinn, L. L. (2001). Telling it slant: Historic house museums and the re-creation of the past. Unpublished Ph.D., The University of Rochester, United States -- New York.

Trautmann, J. (1999). Dress, furnishings and interiors, c1910--1918, Minneapolis, Minnesota: Exploring design relationships in the context of the Purcell-Cutts House.Unpublished Ph.D., University of Minnesota, United States -- Minnesota.

Wieber, S. (2004).Designing the nation: Neo-Northern Renaissance interiors and the politics of identity in late nineteenth-century Germany, 1876--1888. Unpublished Ph.D. 3125652, The University of Chicago, United States -- Illinois.

Alternative Delivery

Bender, D. M. (2002). Attitudes of higher education interior design faculty toward the innovation of distance education.Unpublished Ph.D., Michigan State University, United 
States -- Michigan.

Botti-Salitsky, R. M. (2005). Evaluation of a virtual design studio for interior design education.Unpublished Ph.D., Capella University, United States -- Minnesota.

Chan, P. K. (2003). A pattern language for design development process of a Web-based online course. Unpublished Ph.D., The Ohio State University, United States -- Ohio.

Charlson, J. K. (2006). Differences between online and traditional instruction methods: Performance and satisfaction in an interior design course.Unpublished Ph.D., Colorado State University, United States -- Colorado.

Kays, E. J. (2003). Architecture and instructional design: A conceptual model for e-learning.Unpublished Ph.D., Capella University, United States -- Minnesota.

National Center for Education Statistics (2008). Digest of Education Statistics.

Nawrocki, S. C. (2001). Interior designers' computer applications in professional practice: Implications for interior design education.Unpublished Ph.D., Mississippi State University, United States -- Mississippi.

Peterson, J. (2009). The Net-generation interior design student: An exploratory study assessing learning and engagement within a computer simulation environment. Unpublished 3360382, University of Minnesota, United States - Minnesota

Ransdell, M. (2009). Design scholar: Examining creative thinking in an online learning community for interior design graduate students. Unpublished 3385985, University of Florida, United States -- Florida.

\section{Teaching Strategies}

Ho, C. (2006). Spatial cognition in design. Unpublished 3248696, Georgia Institute of Technology, United States -- Georgia.

Karpan, C. M. (2005).A theoretical framework for research in interior design: Implications for post-secondary interior design education in Canada and the United States. Unpublished NR05186, University of Manitoba (Canada), Canada.

Pungthong, V. (2004). Drawing for communication. Unpublished Ph.D., The Ohio State University, United States -- Ohio.

Schultz, T. L. (2001). Concept maps vs. embedded questions: Assessing cognitive change in interior design students. Unpublished Ph.D., The University of Toledo, United States --Ohio.

Tural, M. (2006). An approach to integrate lighting concepts into interior design studios: A constructivist educational framework. Unpublished Ph.D., BilkentUniversitesi (Turkey), Turkey.

Wright-Evans, K. M. (2001). R2D2 goes to work: The design and development of a first-year art foundations course. Unpublished Ph.D., Iowa State University, United States -- Iowa. 


\section{Macrothink}

Vaikla-Poldma, T. (2003). An investigation of learning and teaching processes in an interior design class: An interpretive and contextual inquiry. Unpublished Ph.D., McGill University (Canada), Canada.

\section{Teaching Environment and Facilities}

Abdul-Hafeez, N. (2005). Identifying the critical aspects of the built environment for effective art education in institutions of higher education. Unpublished 3217059, The Florida State University, United States -- Florida.

Burruss, W. J., Jr. (2004). Adult learning environments: Request upon and preferences of interior designers. Unpublished 3152156, Oklahoma State University, United States -Oklahoma.

Haviarova, E. (2000). Design and construction of wooden school furniture for children in developing countries (Central America).Unpublished Ph.D., Purdue University, United States -- Indiana.

Kent, K. (2009). The coffee house classroom: The difference between student and faculty perceptions of classroom spatial design in a community college environment. Unpublished 3374717, Indiana State University, United States -- Indiana.

Lawrence, D. D. (1999). The lived experience of teachers in a restructured elementary school.Unpublished Ph.D., Purdue University, United States -- Indiana.

\section{Copyright Disclaimer}

Copyright reserved by the author(s).

This article is an open-access article distributed under the terms and conditions of the Creative Commons Attribution license (http://creativecommons.org/licenses/by/3.0/). 